\title{
Hydrogeophysical Implication of Geoelectric Sounding at Igarra Comprehensive High School, Akoko Edo Local Government, Nigeria
}

\author{
Adediran Olanrewaju Adegoke ${ }^{1}$, E. Rotimi Olafisoye ${ }^{2}$, \\ Oluwatoyin Ologe ${ }^{3}$ \\ ${ }^{1}$ Department of Physical Sciences (Geophysics Programme), Olusegun Agagu University of Science and \\ Technology (OAUSTECH), Okitipupa, Ondo, Nigeria. \\ ${ }^{2}$ Department of Physical Sciences (Geophysics Programme), Olusegun Agagu University of Science and \\ Technology (OAUSTECH), Okitipupa, Ondo, Nigeria. \\ ${ }^{3}$ Department of Applied Geophysics, Federal University Birnin Kebbi, Kebbi State, Nigeria.
}

Corresponding Author: Adediran Olanrewaju Adegoke

\begin{abstract}
Electrical resistivity method was used to carry out hydrogeophysical study in order to evaluate the groundwater potential of Igarra Comprehensive High School, Akoko Edo Local Government, Nigeria. The vertical electrical sounding technique (VES) was adopted for the resistivity method. A total of eighteen electrical soundings were conducted across the area using the Schlumberger electrode array with $A B / 2$ varying from 1 to $65 \mathrm{~m}$. After the data acquisition, interpretation was carried out qualitatively and quantitatively and the results were presented as sounding curves, tables, charts, maps and geoelectric sections. The generated geoelectric layers from the sounding curves revealed four geologic layers: the topsoil, the weathered layer, the partially weathered/fractured basement and the fresh basement with their resistivity values ranging from 129.1 to $956.4 \Omega-\mathrm{m}, 6.8$ to $1491.1 \Omega-\mathrm{m}$, 261.3 to $776.6 \Omega-m$ and 1515.6 to $2653.5 \Omega-m$ respectively. The overburden thickness in the study area varies from 5.5 to $23.5 \mathrm{~m}$. The groundwater potential map enabled in the classification of the study area into: low, medium and high groundwater potential area. About $85 \%$ of the study area falls within the low groundwater potential rating while about $10 \%$ constitutes the medium groundwater potential rating and the remaining 5\% constitutes high groundwater potential rating.
\end{abstract}

Keywords: Groundwater, overburden, electrical resistivity, basement, geoelectric sounding.

\section{INTRODUCTION}

Groundwater is used for various purposes in both the developed and developing countries. Among its major purposes are for use in municipal, agriculture and industries, often extracted through the construction of wells and boreholes. In most parts of the countries where there is no (or limited) supply of freshwater from the surface water sources, groundwater serves the alternative natural sources. In Nigeria, large portions of its freshwater usage come from groundwater sources. The regional distribution of groundwater within the earth varies and this depends on the geology of the subsurface. The concealed basement rocks may contain faulted areas, incipient joints and fractured systems derived from earlier tectonic events. The detection of and delineation of these hydrogeologic structures may facilitate the location of groundwater prospect zones in typical basement settings (Omosuyi et al., 2003; Satpatty and Kanugo, 1976). Groundwater resource is fairly evenly distributed throughout the world. This account for about $98 \%$ of the world's fresh water needs. It provides a reasonable 
constant supply which is not in most cases completely susceptible to drying up under natural conditions unlike surface water. The electrical resistivity survey has been widely used for hydrogeological investigation to obtain subsurface information on geological structures, aquifer delineation and lithologic boundaries (Asiwaju-Bello et al., 2013; Bose et al., 1973; Omosuyi, 2001). This method helps to provide detailed information on groundwater studies in both the basement complex terrains and sedimentary environment (Barongo and Palacky, 1991; De Beer and Blume, 1985; Mbonu et al., 1991; Olayinka and Olorunfemi, 1992; Olorunfemi et al., 1999). The water supply for the staffs and the students of Igarra Comprehensive High School comes from outside the school compound. The entire population of this community depends on the wells drilled at some distances located outside the school premises. As the need may arise in the nearest future for groundwater development through borehole or well, hydrogeophysical investigation was carried to understand better the groundwater potential of this area.

\section{DESCRIPTION AND GEOLOGY OF THE STUDY AREA}

The study area is located in Igarra which is the headquarter of Akoko - Edo Local Government area in Edo State. It lies between latitude $7^{\circ} 17^{\prime} 26.27^{\prime \prime} \mathrm{N}$ and $7^{\circ} 1^{\prime} 7^{\prime}$ $33.79 " \mathrm{~N}$ and longitude $6^{\circ} 5^{\prime} 43.55^{\prime \prime} \mathrm{E}$ and $6^{\circ}$ $5 ' 49.78 "$ E. The study area occupies about $44,390 \mathrm{~m}^{2}$. This location is accessible through tarred roads and major footpaths. The terrain is gently undulating with topographic elevation ranging between 295 and $316 \mathrm{~m}$ above sea level. The area is underlain by the Precambrian basement complex of southwestern Nigeria (Rahaman, 1989). Some of the rock types identified within this area and its surroundings are migmatites, charnokites, metasediments (Marble, Quartzites, Metaconglomerates and Schists) among others.

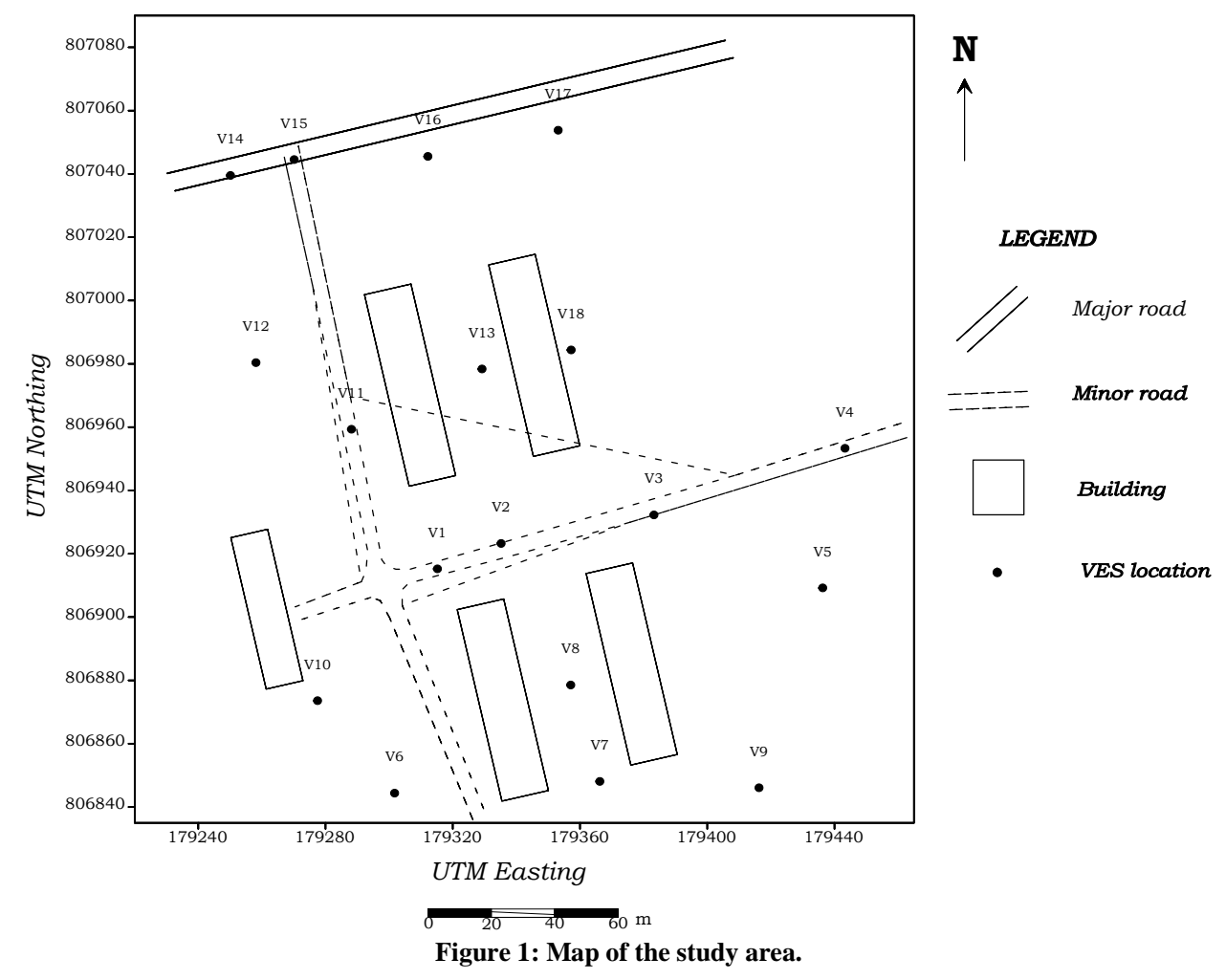

\section{MATERIAL AND METHODS}

The materials used for the study include the following: ohmega resistivity meter, four metallic electrodes (which consist of two current and two potential electrodes), four connecting cable reels, 
Adediran Olanrewaju Adegoke et.al. Hydrogeophysical implication of geoelectric sounding at Igarra Comprehensive High School, Akoko Edo Local Government, Nigeria.

measuring tape, hammers (for electrodes driving into the ground), compass (for finding the North direction), cutlass for cutting, data sheet (for recording the field data) and Global Positioning System (GPS). Both the current and potential electrodes were connected to the resistivity meter through the four reels of wire. Current was introduced into the ground via currents electrodes and the resulting potential differences were measured through the potential electrodes. Vertical electrical sounding (VES) technique was adopted using Schlumberger array with maximum half spread length $(A B / 2)$ of $100 \mathrm{~m}$. A total eighteen VES was acquired across the study area. The field data were used to derive sounding curves by plotting apparent resistivity against $A B / 2$ or half the spread length on a bi-log paper. Geoelectric parameters derived from manual interpretation were later used as a starting model for computer-assisted interpretation (Vander Velpen, 2004).

\section{RESULTS AND DISCUSSION}

The results of this study are presented as sounding curves, tables, charts, maps and geoelectric sections. Table 1 shows the summary of geoelectric parameters derived from each VES. The curve types obtained were $\mathrm{H}, \mathrm{QH}, \mathrm{KH}$, KQH, KHA and HA (Table 1 and Figure 2). The predominant curve type is the $\mathrm{H}$ curve type having percentage frequency of $44.4 \%$. The remaining curves types $\mathrm{QH}, \mathrm{KH}, \mathrm{KQH}$, KHA and HA have percentage frequencies of $27.8,11.1,5.6,5.6$ and $5.6 \%$ respectively (Figure 2). Typical sounding curve obtained from the study are shown in Figure 3a and b.

Table 1:

\begin{tabular}{|c|c|c|c|c|c|c|c|c|c|c|}
\hline \multirow[t]{2}{*}{ VES NO. } & \multicolumn{5}{|c|}{ Resistivity $(\Omega \mathrm{m})$} & \multicolumn{4}{|c|}{ Thickness (m) } & \multirow[t]{2}{*}{ Curve type } \\
\hline & $\rho_{1}$ & $\rho_{2}$ & $\rho_{3}$ & $\rho_{4}$ & $\rho_{5}$ & $\mathbf{h}_{1}$ & $\mathbf{h}_{2}$ & $\mathbf{h}_{3}$ & $\mathbf{h}_{4}$ & \\
\hline 1 & 788 & 69 & 338 & & & 1.2 & 21.8 & & & $\mathrm{H}$ \\
\hline 2 & 352 & 43 & 527 & & & 1.5 & 22.0 & & & $\mathrm{H}$ \\
\hline 3 & 744 & 267 & 39 & 681 & & 0.8 & 2.9 & 10.4 & & $\mathrm{QH}$ \\
\hline 4 & 332 & 603 & 47 & 485 & & 0.6 & 1.4 & 10.8 & & $\mathrm{KH}$ \\
\hline 5 & 282 & 762 & 39 & 480 & & 0.5 & 1.5 & 9.3 & & $\mathrm{KH}$ \\
\hline 6 & 635 & 265 & 17 & 413 & & 1.4 & 1.1 & 12.3 & & $\mathrm{QH}$ \\
\hline 7 & 956 & 345 & 30 & 508 & & 1.4 & 2.5 & 10.3 & & $\mathrm{QH}$ \\
\hline 8 & 598 & 421 & 34 & 318 & & 1.4 & 2.0 & 13.2 & & $\mathrm{QH}$ \\
\hline 9 & 404 & 1491 & 225 & 30 & 486 & 0.6 & 1.2 & 1.4 & 9.0 & $\mathrm{KQH}$ \\
\hline 10 & 217 & 32 & 535 & & & 1.4 & 13.8 & & & $\mathrm{H}$ \\
\hline 11 & 251 & 124 & 315 & & & 1.1 & 4.4 & & & $\mathrm{H}$ \\
\hline 12 & 445 & 77 & 665 & & & 0.6 & 4.9 & & & $\mathrm{H}$ \\
\hline 13 & 161 & 329 & 76 & 261 & 3453 & 0.4 & 0.6 & 10.9 & 11.7 & KHA \\
\hline 14 & 129 & 24 & 614 & & & 0.9 & 16.0 & & & $\mathrm{H}$ \\
\hline 15 & 332 & 22 & 775 & & & 1.5 & 11.6 & & & $\mathrm{H}$ \\
\hline 16 & 652 & 177 & 17 & 706 & & 1.2 & 1.6 & 6.2 & & $\mathrm{QH}$ \\
\hline 17 & 606 & 249 & 7 & 452 & 2654 & 0.7 & 1.2 & 6.0 & 5.9 & HA \\
\hline 18 & 409 & 102 & 777 & & & 1.0 & 15.9 & & & $\mathrm{H}$ \\
\hline
\end{tabular}
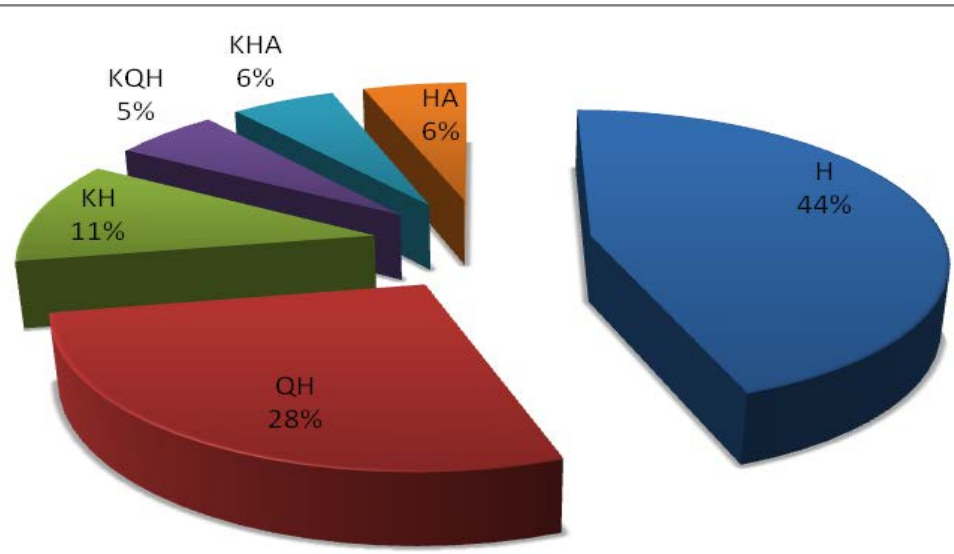

Figure 2: Pie chart showing percentage frequency of curve types within the study area. 
Adediran Olanrewaju ADEGOKE et.al. Hydrogeophysical implication of geoelectric sounding at Igarra Comprehensive High School, Akoko Edo Local Government, Nigeria.

\section{Geoelectric sections}

Figures $4 \mathrm{a}$ to $4 \mathrm{~b}$ show the two generated geoelectric sections in the NE SW and W - E directions respectively. The geoelectric sections represent the twodimensional figures of the variation of resistivity and thickness of each geoelectric layer beneath each VES location connected along a profile. In these geoelectric sections, four geologic subsurface layers comprising the topsoil, the weathered layer, the weathered basement and fresh basement rock were identified. The topsoil varies in composition from sandy clay, clayey sand to laterite with resistivity varying from 129.1 $\Omega-\mathrm{m}$ to $956.4 \Omega-\mathrm{m}$. The topsoil thickness varies from $0.5 \mathrm{~m}$ to $1.5 \mathrm{~m}$. The weathered layer is characterised by resistivity ranging from $6.8 \Omega$-m to $1491.1 \Omega-m$. The thickness of this unit varies from $0.6 \mathrm{~m}$ to $22.0 \mathrm{~m}$. Directly lying beneath the weathered layer is the weathered basement with the resistivity ranges of $261.3 \Omega-\mathrm{m}$ to $776.6 \Omega$ $\mathrm{m}$. The thickness of this layer varies from $0.5 \mathrm{~m}$ to $11.7 \mathrm{~m}$. The fresh basement resistivity varies from $1515.6 \Omega-m$ to $2653.5 \Omega-\mathrm{m}$.
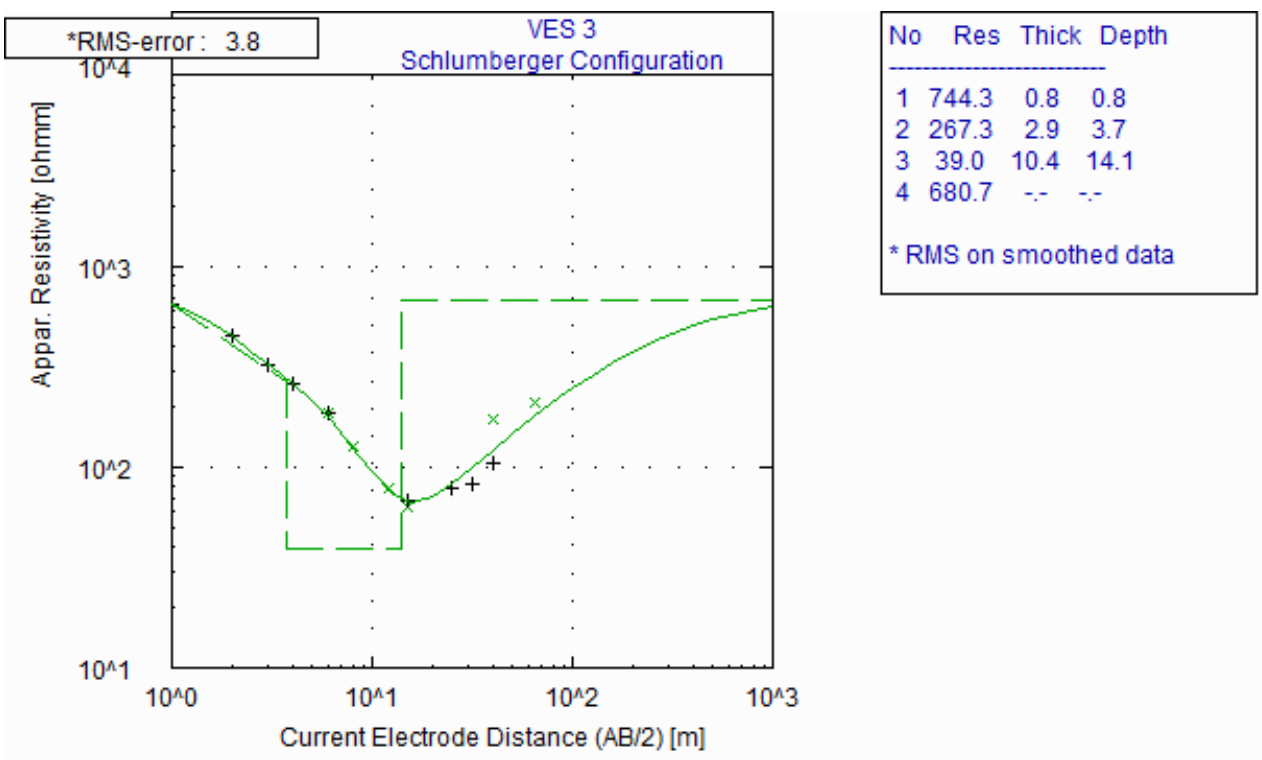

Figure 3a: Typical sounding curve from the study area.
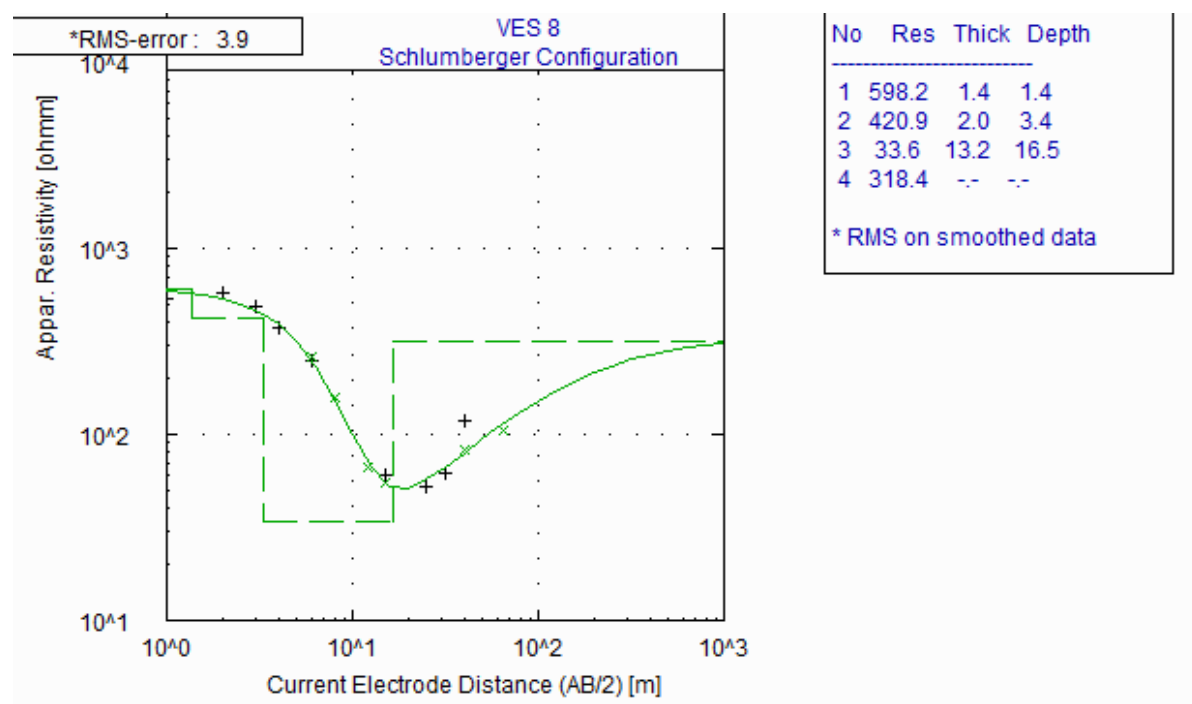

Figure 3b: Typical sounding curve from the study area. 
Adediran Olanrewaju Adegoke et.al. Hydrogeophysical implication of geoelectric sounding at Igarra Comprehensive High School, Akoko Edo Local Government, Nigeria.

(a)

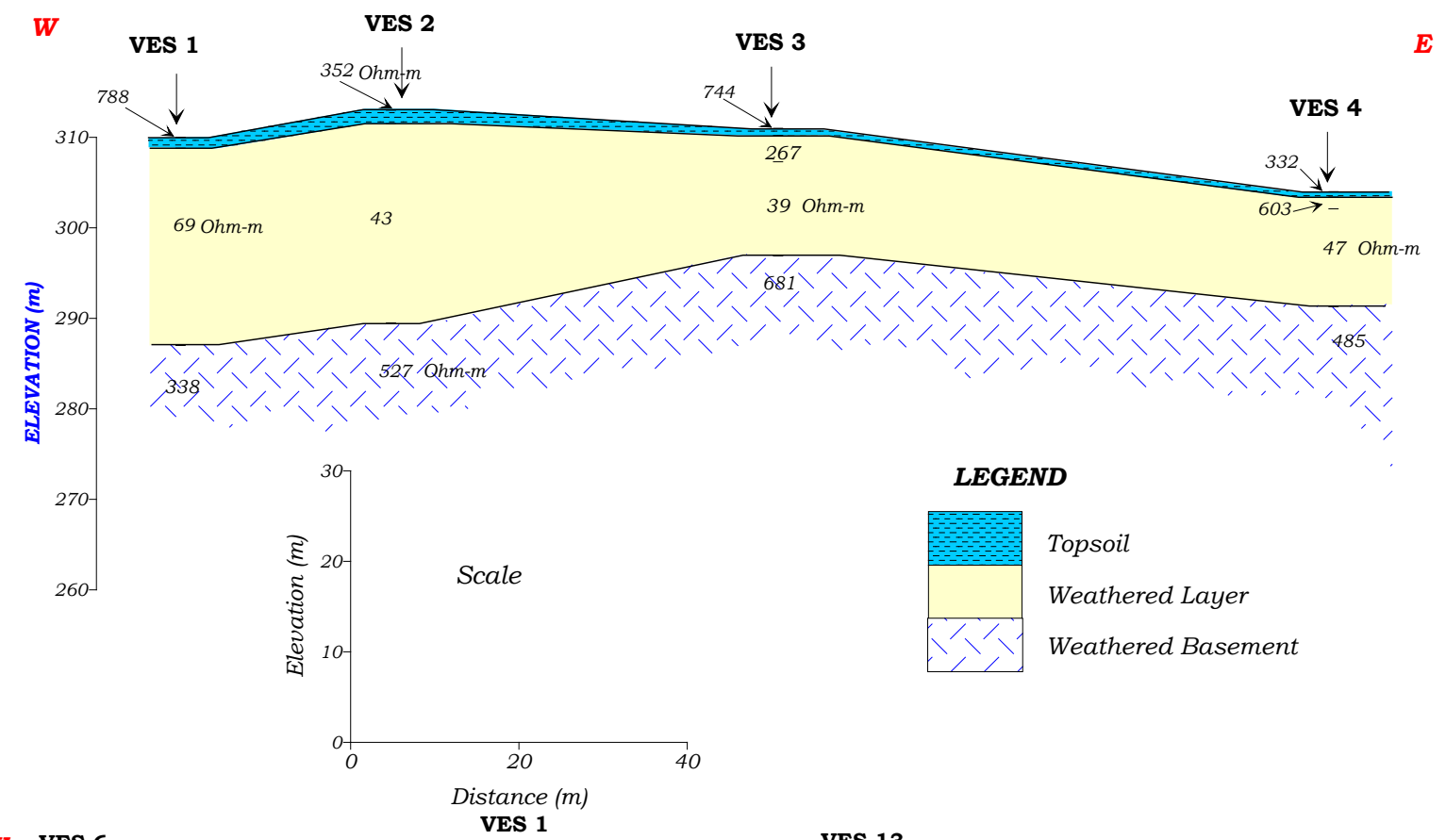

(b)

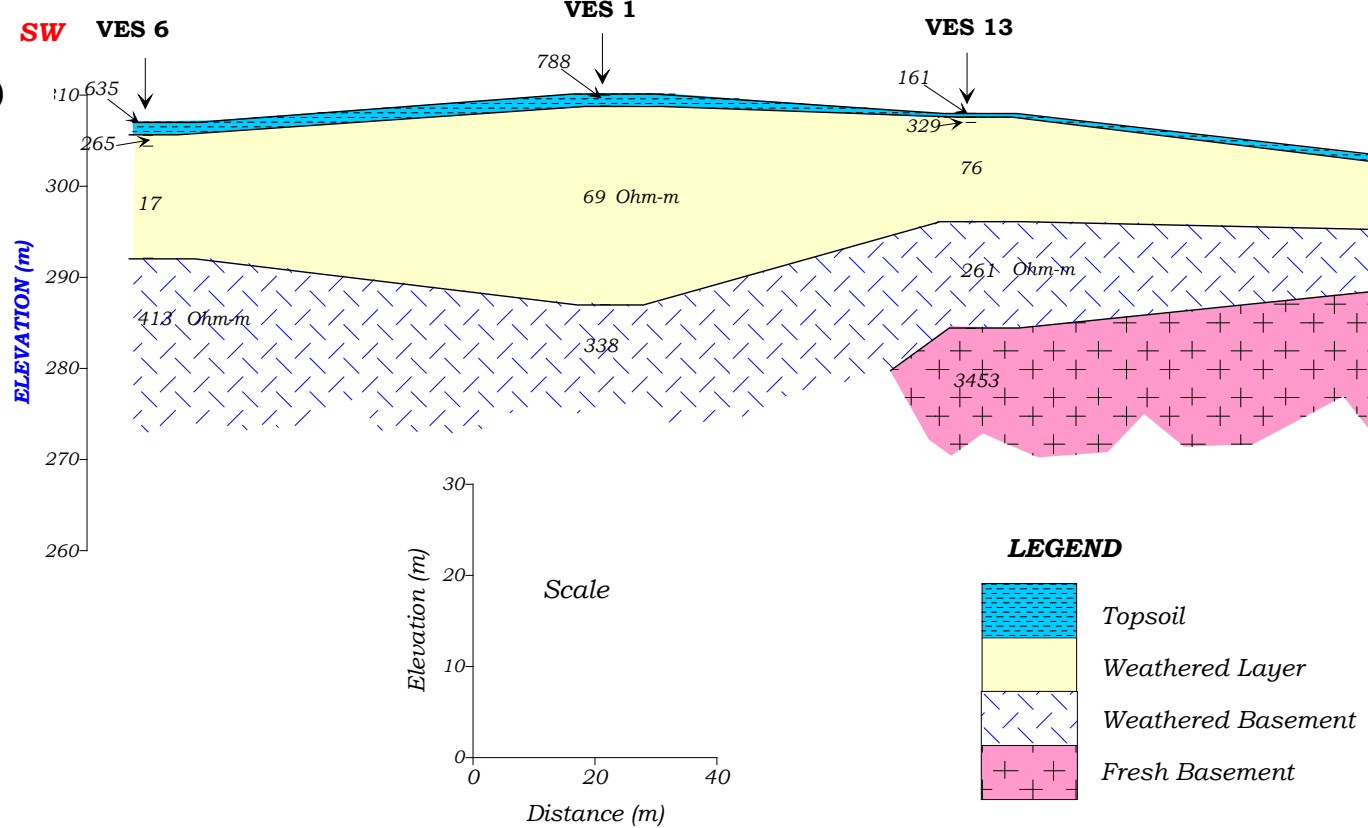

Figure 4: Geoelectric sections along (a) West - East (W - E) and (b) Southwest - Northeast (SW - NE).

Isopach map of the overburden and Groundwater potential evaluation of the study area

Figure 5 reveals the delineated depth from the surface to the basement beneath the VES stations. The overburden thickness in the area varies from $5.5 \mathrm{~m}$ to $23.5 \mathrm{~m}$ and this comprises of the topsoil and the weathered layer. The relevant parameters always used in the evaluation of the groundwater potential are the thickness of the overburden, the resistivity and the thickness of the weathered basement. Figure
6 shows the groundwater potential map of the study area. The groundwater potential evaluation helped in classifying the area into low, medium and high groundwater potential area. Almost at the centre of the study area which is the area occupied VES 1 and 2 fall within the high groundwater potential area. This area is characterised by very thick overburden (above $22.0 \mathrm{~m}$ ) and low weathered basement resistivity values (range from 338.0 to $526.6 \Omega-\mathrm{m}$ ) which is an indication of high saturation condition. The major part of the study area estimated 
Adediran Olanrewaju Adegoke et.al. Hydrogeophysical implication of geoelectric sounding at Igarra Comprehensive High School, Akoko Edo Local Government, Nigeria.

to be $85 \%$ of the total area falls within the medium groundwater potential area. The remaining area indicated with pink colour on the map (Figure 6) constitutes the low groundwater potential area.

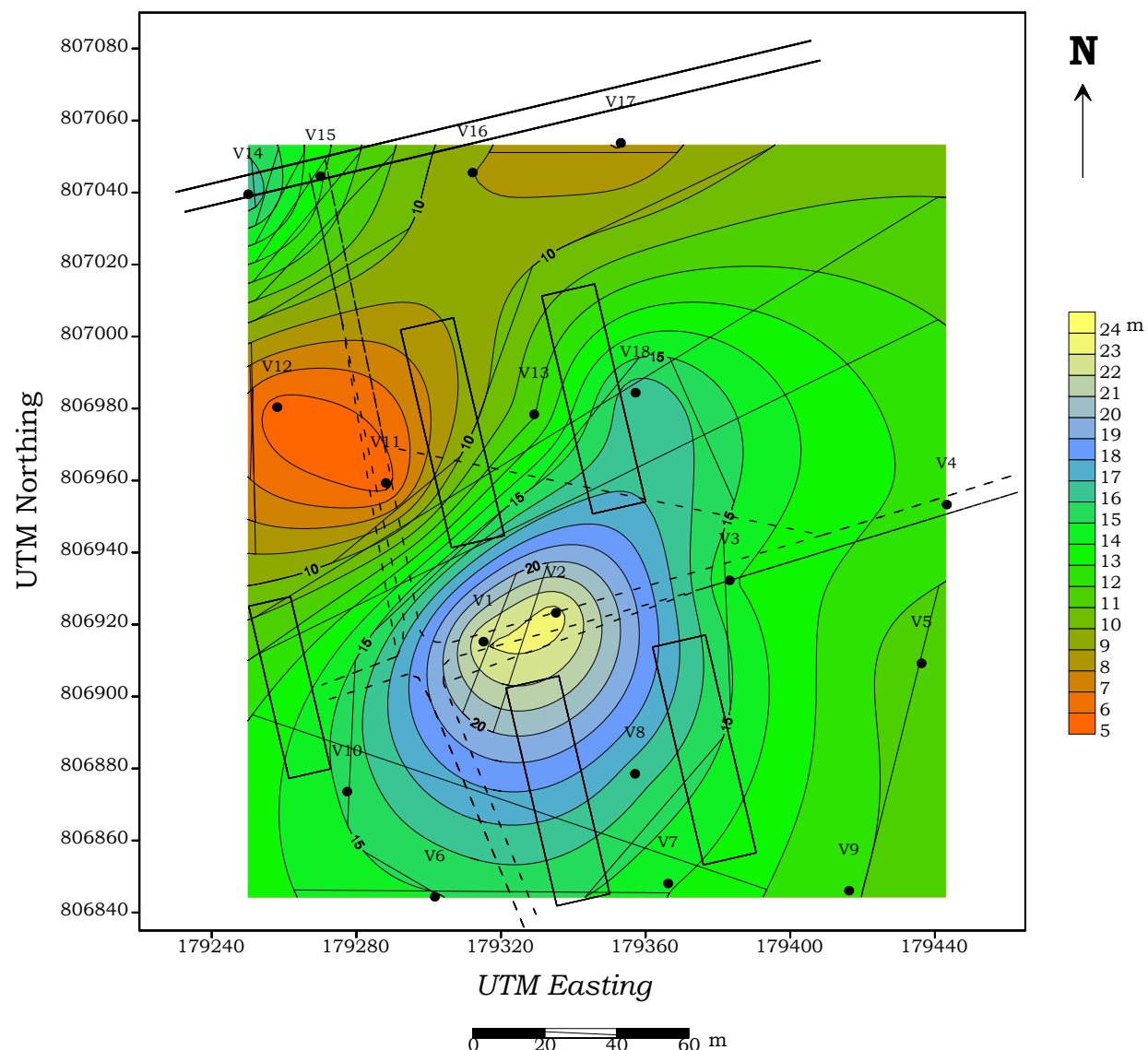

Figure 5: Isopach map of overburden.

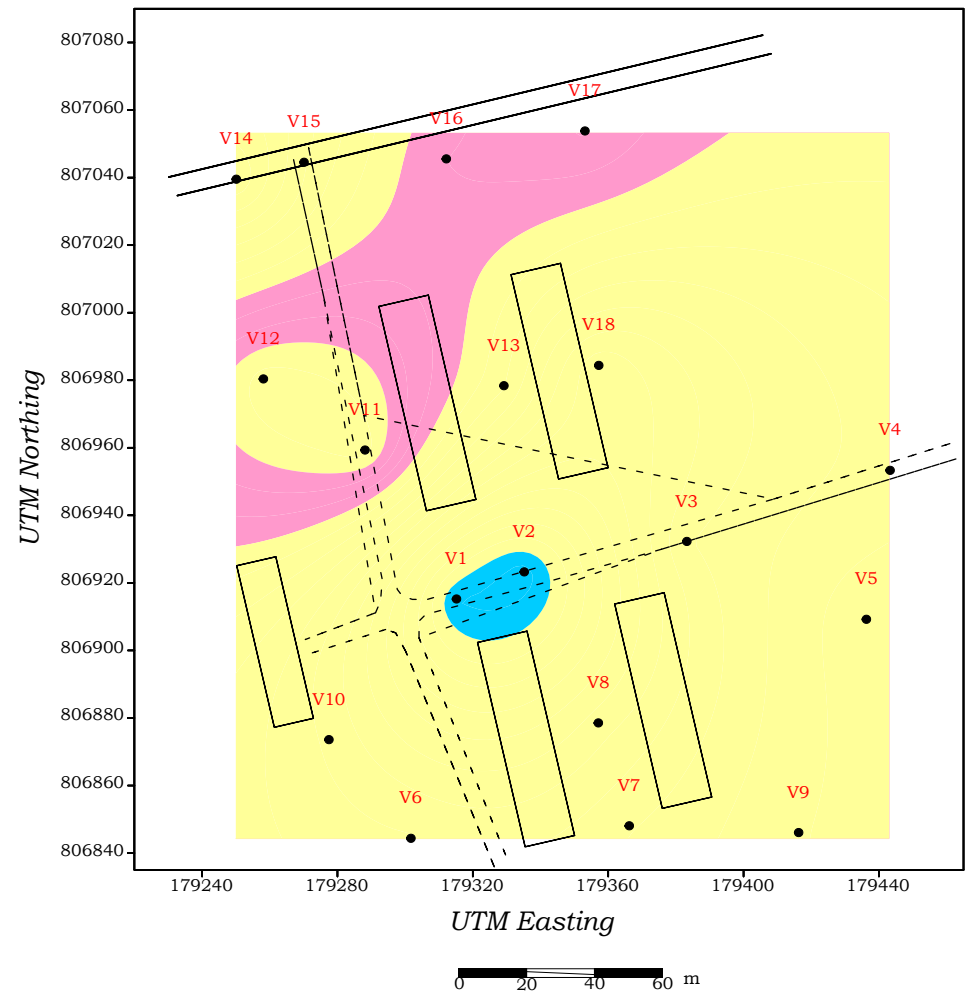

$\mathbf{N}$

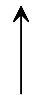

LEGEND

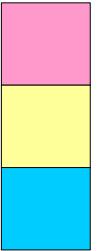

Low Groundwater Potential area

Medium Groundwater Potential area

High Groundwater Potential area

Figure 6: Groundwater potential map of the study area. 


\section{CONCLUSION}

This study has successfully shown the hydrogeophysical implication of geoelectric sounding in evaluating the groundwater potential of Igarra comprehensive high school. The investigation has been helpful in the delineation and characterization of aquifer unit. Four geologic subsurface layers namely the topsoil, the weathered layer, the weathered basement and fresh basement rock were delineated. The results enabled in the zoning the area into low, medium and high groundwater potential area.

\section{Conflict of Interest: None}

\section{REFERENCES}

1. Asiwaju-Bello YA, Ololade JO(2013). Groundwater Potential of Basement Aquifers in Part of Southwestern Nigeria; America International Journal of Contemporary Research, Vol. 3, No 3, pp. 124.

2. Barongo JO, Palacky GJ (1991). Investigations of electrical properties of weathered layers in the Yala area, Western Kenya, using resistivity soundings. Geophys. 56(O.I): 133-138.

3. Bose KN, Chatterjee D, Sen AK (1973). Electrical resistivity surveys for groundwater in the Aurangabad Subdivision, Gaya District, Bihar, Indian pp. 171-181.

4. De Beer JH, Blume J (1985). Geophysical and Hydrogeological investigations of the Groundwater resources of Western Hereroland, South west Africa/Namibia Trans, Geol. Soc. S. Africa, 88: 483-493.

5. Mbonu PDC, Ebeniro JO, Ofoegbu CO, Ekine AS (1991). Geoelectric sounding for the determination of aquifer characteristics in parts of the Umuahia area of Nigeria. Geophys. 56(2): 284-291.

6. Olayinka AI, Olorunfemi MO (1992). Determination of geoelectrical Characteristic in Okene Area and implication for boreholes setting. J. Min. Geol., 28: 403 - 412.

7. Olorunfemi MO, Ojo JS, Akintunde OM (1999). Hydrogeophysical evaluation of the groundwater potential of Akure metropolis, southwestern Nigeria. J. Min. Geol. 35(2):207-228.

8. Omosuyi, G.O. (2001). Geophysical and Hydrogeological Investigations of Groundwater Prospects in the Southern Part of Ondo State, Nigeria. Ph.D. Thesis, Department of Applied Geophysics, Federal University of Technology, Akure, 195.

9. Omosuyi, G.O., Ojo, J.S. and Enikanselu, P.A. (2003). Geophysical Investigation for Groundwater around Obanla-Obakekere in Akure Area within the Basement Complex of South-Western Nigeria. Journal of Mining and Geology. 39(2):109-116.

10. Rahaman MA (1989). Review of the basement geology of southwestern Nigeria: In Geology of Nigeria (Kogbe CA Ed.). Elizabeth Publishing. Co. Nigeria. pp. 4158.

11. Satpatty BN, Kanugo BN (1976). Groundwater Exploration in Hard rock terrain, a Case study, Geophysical Prospecting, 24 (4): 725 - 736.

12. Vander Velpen, B.P.A. 2004. "Resist Version 1.0". M.Sc. Research Project. ITC: Delft, Netherlands.

How to cite this article: Adediran Olanrewaju Adegoke, E. Rotimi Olafisoye, Oluwatoyin Ologe. Hydrogeophysical implication of geoelectric sounding at Igarra Comprehensive High School, Akoko Edo Local Government, Nigeria. International Journal of Research and Review. 2021; 8(12): 411-417. DOI: https:// doi.org/10.52403/ijrr.20211250 